\title{
Translation and Linguistic Validation of Korean Version of the Expanded Prostate Cancer Index Composite for Clinical Practice for Patients With Prostate Cancer
}

\author{
Young Cheol Hwang ${ }^{1}$, Sung Yong Cho ${ }^{1}$, Ja Hyun $\mathrm{Ku}^{1}$, Seong Jin Jeong' ${ }^{2}$, Seung-June $\mathrm{Oh}^{1}$ \\ ${ }^{1}$ Department of Urology, Seoul National University Hospital, Seoul National University College of Medicine, Seoul, Korea \\ ${ }^{2}$ Department of Urology, Seoul National University Bundang Hospital, Seoul National University College of Medicine, Seongnam, Korea
}

Purpose: Advances in the diagnosis and treatment of prostate cancer have increased the patients' stress level and decreased the quality of life. A variety of instruments are currently available to evaluate patients with prostate cancer. However, only a few tools are available to assess Korean patients, and therefore we demonstrated a linguistic validation of Korean Expanded Prostate Cancer Index Composite for Clinical Practice (EPIC-CP).

Methods: EPIC-CP was translated into Korean and the linguistic validation was evaluated. The evaluation process includes permission for translation, forward translation, reconciliation, backward translation, cognitive debriefing, and proofreading. Two bilingual translators independently translated the original questionnaire, discussed the feasibility and naturalness of initial translation, followed by revision to the reconciled version. Another translator then performed a backward translation into English. Ten patients with prostate cancer completed the translated questionnaire and performed cognitive debriefing.

Results: The original EPIC-CP was translated into 2 Korean versions. The different wording in both versions and the ordinary words in the initial translations were changed considering the nuances and meanings of medical terms. During the backward translation, the panels made slight changes to clarify the meaning and nuances of the translated questionnaire. During cognitive debriefing, 10 patients answered the questionnaire and offered their opinions regarding comprehensibility and naturalness. Most patients agreed that the translation was comprehensible in general.

Conclusions: Our study provides a successful linguistic validation of the EPIC-CP questionnaire. The translation is a helpful diagnostic tool to ensure the quality of life of patients with prostate cancer attending crowded clinics.

Keywords: Prostate cancer; Quality of life; Questionnaires; Linguistic validation; Patient-Reported Outcome

- Research Ethics: This study was approved by the Institutional Review Board of Seoul National University of Hospital (approval number: H-1305-033-487).

- Conflict of Interest: SYC, a member of the Editorial Board of International Neurourology Journal, is the corresponding author of this article. However, he played no role whatsoever in the editorial evaluation of this article or the decision to publish it. No potential conflict of interest relevant to this article was reported.

Corresponding author: Sung Yong Cho (iD https://orcid.org/0000-0001-9271-6951 Department of Urology, Seoul National University Hospital, Seoul National University College of Medicine, 101 Daehak-ro, Jongno-gu, Seoul 03080, Korea Email: moretry@yahoo.com

Submitted: August 26, 2020/Accepted after revision: October 13, 2020
This is an Open Access article distributed under the terms of the Creative Commons Attribution Non-Commercial License (https://creativecommons.org/licenses/by-nc/4.0/) which permits unrestricted non-commercial use, distribution, and reproduction in any medium, provided the original work is properly cited. 


\section{INTRODUCTION}

Since survivorship of patients, diagnosed with prostate cancer, has improved because of developments in diagnosis and treatment, Health-related quality of life (HRQoL) during the treatment of prostate cancer is emphasized. A natural course of HRQoL during treatment of prostate cancer is well documented, but objective analysis of such changes during clinical practice is a challenge [1].

The 50-item Expanded Prostate Cancer Index Composite for Clinical Practice (EPIC-CP) has been used to validate questionnaires. It was designed by UCLA Prostate Cancer Index to objectively evaluate $\mathrm{HRQoL}$ after prostate cancer management $[2,3]$. The 50-item EPIC-CP was reduced into a shorter form (EPIC-26) [4]. However, it was still tedious to administer in a busy clinical setting. Therefore, Chang et al. [5] proposed a simpler version of a validated questionnaire to assess HRQoL after prostate cancer management.

The authors of previous studies developed validated Korean versions of various questionnaires such as ISC-Q (Intermittent Self-Catheterization Questionnaire), BSW (Benefit, Satisfaction, and Willingness to Continue Treatment, and OAB-SAT-q (OverActive Bladder Satisfaction with Treatment Questionnaire) [6-9]. Given the increasing prevalence and social effects of prostate cancer on Korean population, a practical tool is needed to evaluate HRQoL and patient-reported outcomes after prostate cancer treatment. However, instruments to assess them in the Korean population are limited. Therefore, we linguistically validated the Korean version of EPIC-CP, which was first proposed by Chang et al. [5].

\section{MATERIALS AND METHODS}

\section{Original Questionnaires}

Chang et al. [5] proposed a handier version of the 50-item EPIC$\mathrm{CP}$ and EPIC-26 for use in clinical practice. The questionnaire is categorized by symptoms: urinary incontinence, lower urinary tract symptoms, sexual function, and hormonal problems.

\section{Translation and Linguistic Validation}

Our study was approved by the Institutional Review Board of Seoul National University Hospital (approval number: H-1305033-487). The linguistic validation was conducted to design a Korean version of EPIC-CP questionnaire, which is conceptually similar to the original work. The validation entailed for- ward translation, reconciliation, backward translation, and cognitive debriefing in order [6-9].

Two bilingual persons took forward translation individually and discussed the difficulties associated with describing the questionnaires in Korean with urologists (SJO and SYC). The experts provided helpful comments to resolve any challenges involving translations and suggested alternative expressions at all steps.

\section{Permission}

The panels requested the original authors who developed EPIC$\mathrm{CP}$ for consent to translate and utilize the questionnaire as a Korean version [5].

\section{Forward Translation}

Both bilingual translators individually rendered the original questionnaire into Korean. They were separated until the translation was completed.

\section{Reconciliation}

The translators and the panels gathered and reviewed 2 forward translated versions and combined it into a single translated questionnaire, for meaning and nuance.

\section{Backward Translation}

The other bilingual translator rendered the reconciled Korean version of EPIC-CP into English. The 3 linguistic experts undertook forward or backward translation, and the panels reviewed the original version of the questionnaire and backward translated version, changing indigestible phrases into more digestible expressions. Finally, the revised version was generated for cognitive debriefing.

\section{Cognitive Debriefing}

The authors administered the revised version of the questionnaire to 10 patients with prostate cancer, who had different educational and regional backgrounds. They were asked to respond to the questionnaire and then notify any difficulties in completing the questionnaire. Well-trained interviewers gathered patients' opinions regarding the challenges encountered. The panels examined the patients' response and then amended the questionnaire accordingly.

\section{Proofreading}

The questionnaire after cognitive debriefing was finally proof- 
read by panels to identify grammatical errors and availability to assess HRQoL after the management of prostate cancer. As a result, we developed the final Korean version of EPIC-CP.

\section{RESULTS}

\section{Forward Translation and Reconciliation}

As given in (Table 1), 10 questions of the EPIC-CP were translated into Korean. The questions can be divided into 4 domains: overall urinary problem, bowel, sexual, vitality, or hormonal domains [5]. English expression of the final questionnaires was based on "Revised Romanization of Korean," proposed by National Academy of the Korean Language

\section{Overall Urinary Problem}

Question 1, "Overall, how much of a problem has your urinary function been for you" in the original questionnaire was translated into "jeonbanjeogeuro gwihaui sobyeongineungi gwihaege eolmana munjega doeeotseumnikka." The expression "urinary function" was translated into "baenyo gineung" and "yorogineung" by translator 1 and 2 repsectively. "baenyo" or "yoro" was considered hard to understand for low-educational persons, so the panels agreed on "sobyeon." "moderate problem" in the original questionnaire was translated into "botong jungdoui munjaega issda" and "munjaega iss da" by translator 1 and 2 respectively, and the panels accepted "junggan jungdoui munjaega issda" because of its nuance.

\section{Urinary Incontinence}

Question 2, "Which of the following best describes your urinary control" in the original questionnaire was translated into "daeum jung gwihaui sobyeon jojeol jeongdoreul gajang jal seolmyeonghago inneun geoseun mueosimnikka." The expression "urinary control" was translated into "baenyo jojeol jeongdoae" and "binyogi jeeo sangtae" by translator 1 and 2 respectively, and the panels accepted "sobyeon jojeol jeongdo," considering patients' educational status. "0 Total control" was translated " 0 wanjeonhi jojeoldoem." "1 Occasional dribbling" was translated into "gakkeumssik sobyeon banguri tteoreojim." "2 Frequent dribbling" was translated into " 2 jaju sobyeon banguri tteoreojim." " 4 No urinary control" was translated into " 4 jeonhyeo jojeolhal su eopseum."

Question 3, "How many pads or adult diapers per day have you been using for urinary leakage" in the original questionnaire was translated into "sobyeoni saegi ttaemune gwihaneun paedeuna seonginyong gijeogwireul harue myeot jang sayonghae watseumnikka." The expression "using for urinary leakage" was translated into "sobyeoni saeneun iyuro" and "binyogiui nuchul ttaemune" by translator 1 and 2 respectively, and the panel accepted "sobyeoni saegi ttaemune." "0 None /1 One pad per day/2 Two pads per day/4 Three or more pads per day" in the original questionnaire was translated into "0 jeonhyeo sayonghaji aneum/1 harue han jang/2 harue du jang/4 harue se jang isang."

Question 4, "How big a problem, if any, has urinary dripping or leakage been for you" in the original questionnaire was translated into "manyak sobyeon banguri tteoreojigeona saen jeogi itdamyeon igeosi gwihaege eolmana keun munjeyeotseumnikka." The expression "if any, has urinary dripping or leakage" was translated into "manyak sobyeon banguri tteoreojigeona saen jeogi itdamyeon igeosi gwihaege eolmana keun munjeyeotseumnikka" and "binyogiui nuchurina bunbi deungui munjega isseotdamyeon" by translator 1 and 2 respectively, and the panels accepted "manyak sobyeon banguri tteoreojigeona saen jeogi itdamyeon."

"CLINICIANS: ADD the answers from questions 2-4 to calculate the Urinary Incontinence Symptom Score (out of 12)" in the original questionnaire was translated into "uisa: yosilgeum jeungsang jeomsu (chongjeom 12jeom jung)reul gyesanhagi wihae 2beoneseo 4beonkkajiui jilmune daehan daedabeul modu deohae juseyo." "Clinician" was translated into "jillyoui" and "imsangui" by translator 1 and 2 respectively and the panels accepted "uisa."

\section{Urinary Irritation/Obstruction}

Question 5, "How big a problem, if any, has each of the following been for you" in the original questionnaire was translated into "manyak daeume haedanghaneun gakgagui jeungsangi itdamyeon gwihaege eolmana keun munjeyeotseumnikka." "a. Pain or burning with urination" was translated into "baenyoreul halttae oneun tongjeungina ttagaum" and "baenyojagyong jung gotongina sseurarim" by translator 1 and 2 respectively, and the panels accepted "sobyeon bol ttae tongjeungina hwakkeungeorim" since "ttagaum" means pricking and "hwakkeungeorim" means closer to burning. "b. Weak urine stream/incomplete bladder emptying" in the original questionnaire was translated into "yakan sobyeon julgi/banggwangeul modu biuji motam (jannyogam)" and "yakan gannyo/baenyo" by translator 1 and 2 respectively, and the panels accepted "yakan sobyeon julgi/banggwangeul modu biuji motam" since "jannyogam" ("incomplete bladder emptying") can be indigestible to low-educational persons. "Need to urinate frequently" in the original questionnaire was translated into "jaju baenyoreul haeya ham" and "jajeun bangnyo" by 

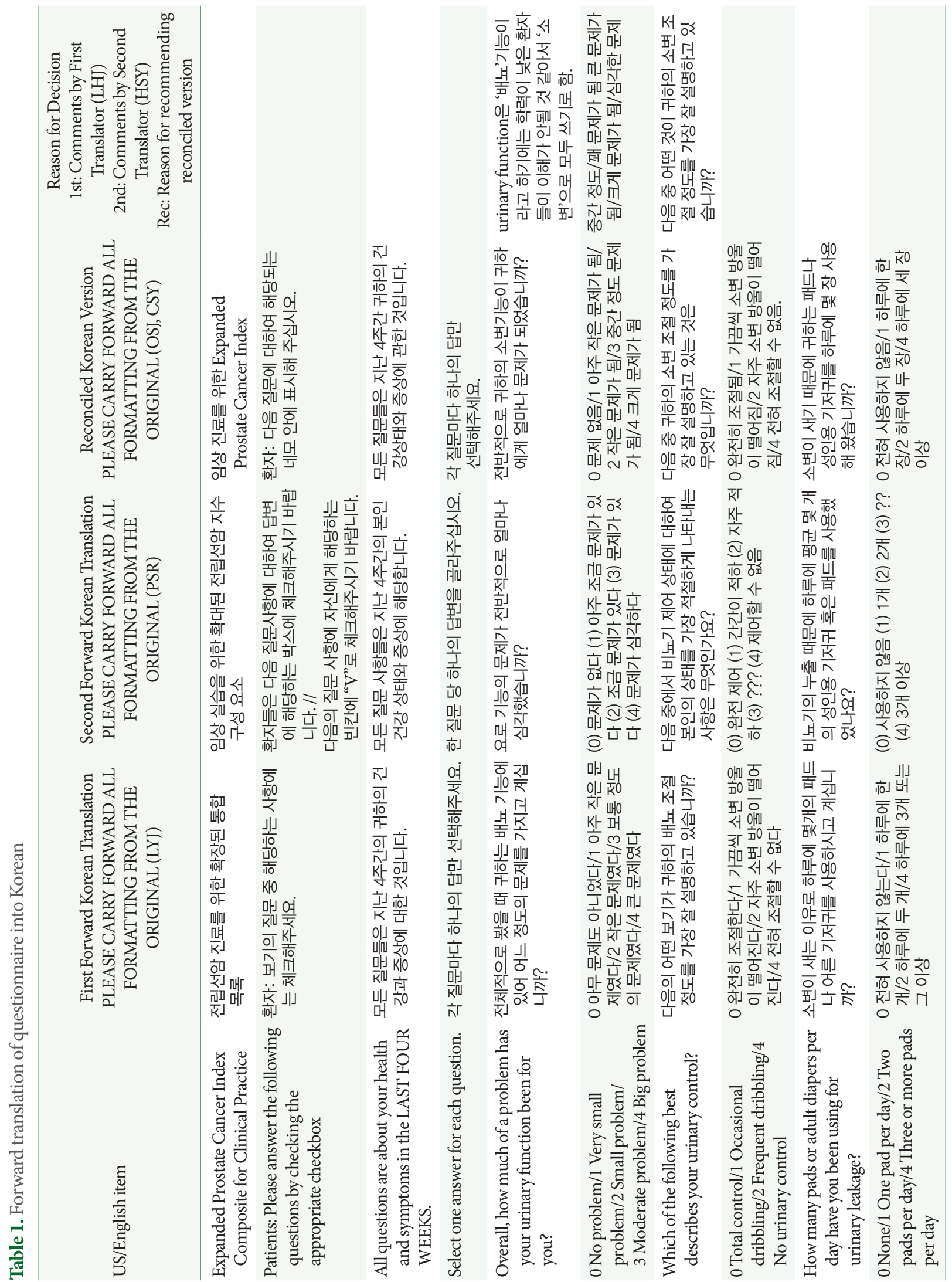







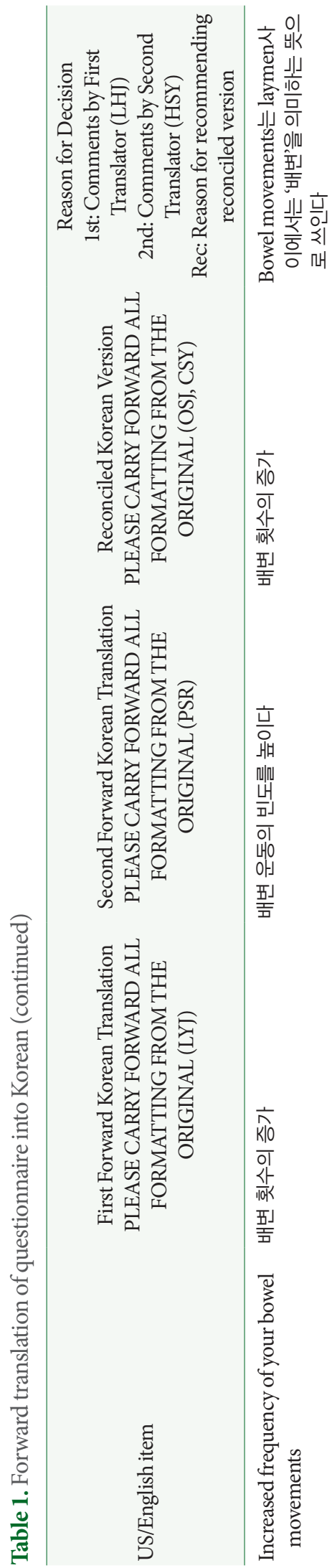

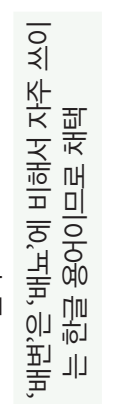
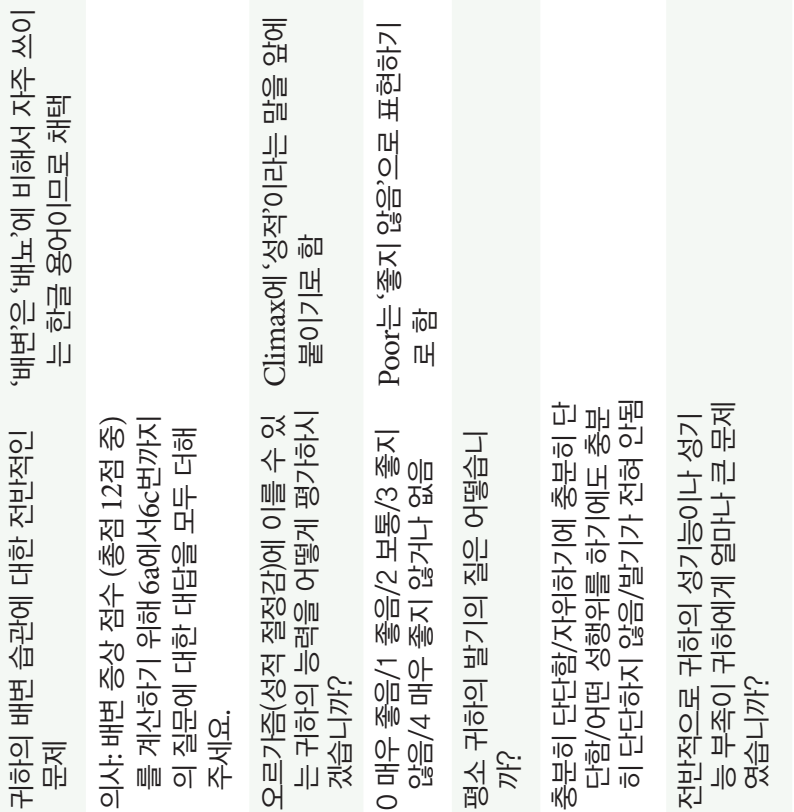



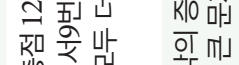

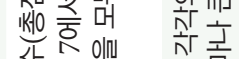





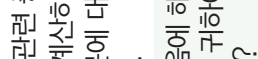

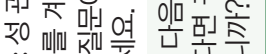

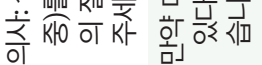

綮

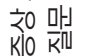

HO $\widehat{K 10}$

아날 어

琶 窇

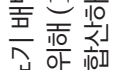

业 암

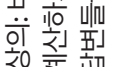

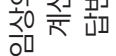

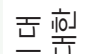

家㐊

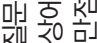

ol $\mathrm{kl}$ 和

인 인 를

琶衣望

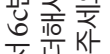

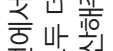

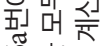

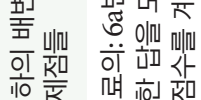

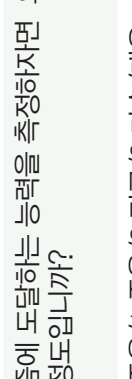

암

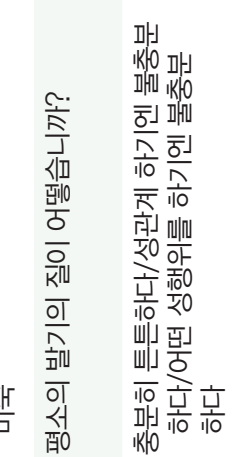

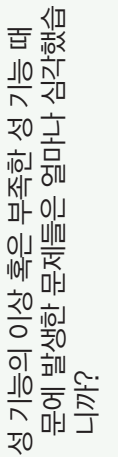

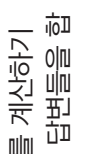

밈ㅁㄴ 미 임

하일 인

₹o 만

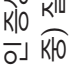

언

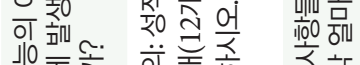

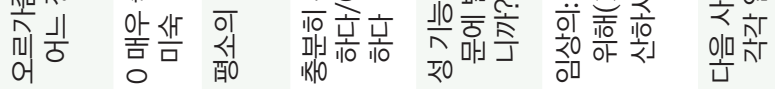

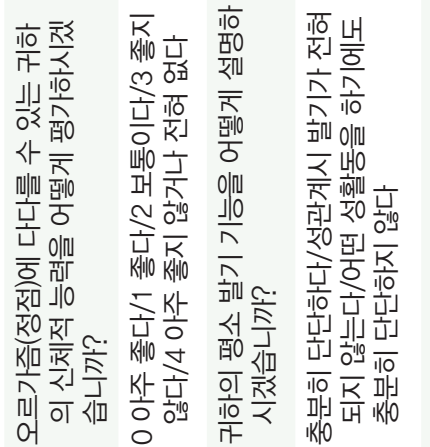

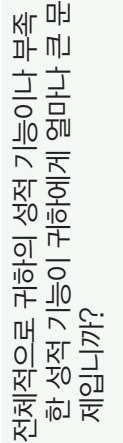

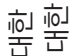

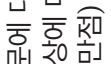



이 荫 $气$

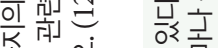

조을 옂

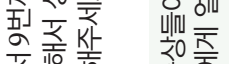

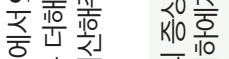

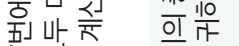

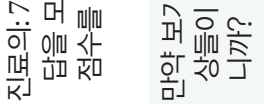

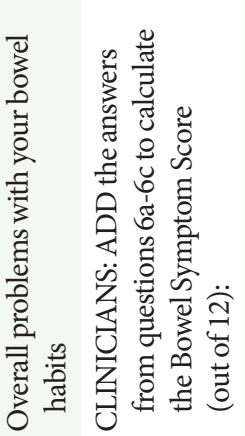

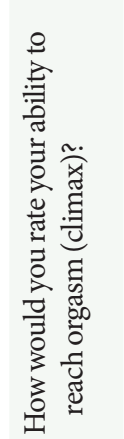

के च

$\ddot{0}$

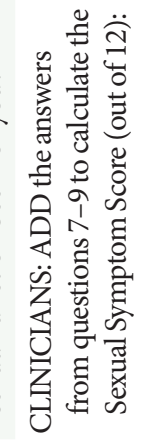




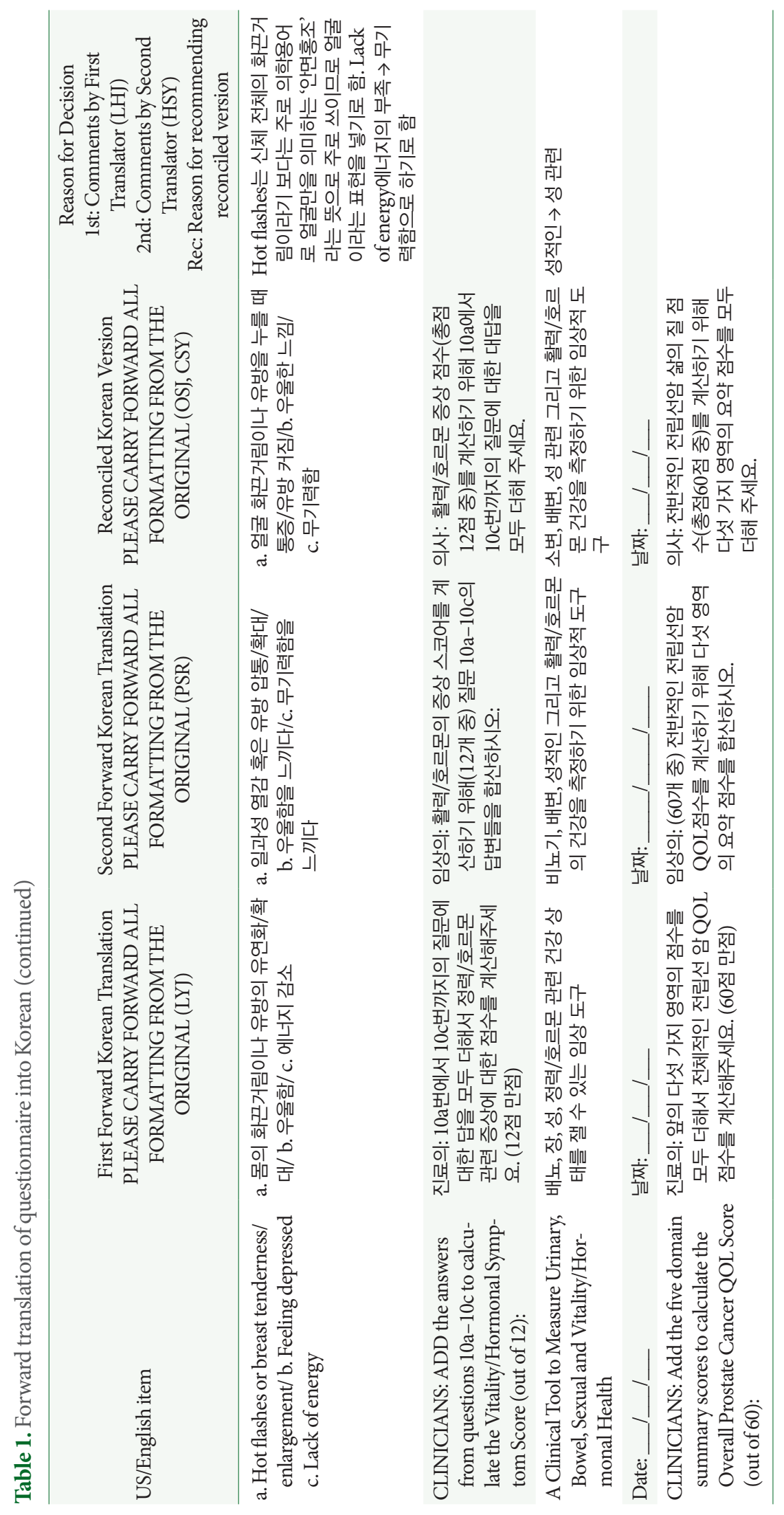


translator 1 and 2 respectively, and the panels accepted "sobyeoneul jaju bwaya ham." "0 No problem/1 Very small problem/2 Small problem/3 Moderate problem 4 Big problem" in the original questionnaire was translated into "0 munje eopseum/1 aju jageun munjega doem/2 jageun munjega doem/3 junggan jeongdo munjega doem/4 keuge munjega doem."

\section{Bowel Symptoms}

Question 6, "a. Rectal pain or urgency of bowel movements" in the original questionnaire was translated into "hangmunui tongjeungina gapjakseureon baebyeon hwaldong" and "jikjangtong hogeun geupan baebyeonundong" by translator 1 and 2 respectively, and the panels accepted "jikjang tongjeung hogeun geupbakan baebyeongam." "b. Increased frequency of your bowel movements" in the original questionnaire was translated into "baebyeon hoetsuui jeungga" and "baebyeon undongui bindoreul nopida" by translator 1 and 2 respectively, and the panels accepted "baebyeon hoetsuui jeungga". "c. Overall problems with your bowel habits" in the original questionnaire was translated into "baebyeon hoetsuui jeungga" and "baebyeon undongui bindoreul nopida" by translator 1 and 2 respectively, and the panels accepted "baebyeon hoetsuui jeungga" since "baebyeon" is more frequently used by ordinary people.

\section{Sexual Symptoms}

Question 7, "How would you rate your ability to reach orgasm (climax)" in the original questionnaire was translated into "oreugajeum (seongjeok jeoljeonggam)e ireul su inneun gwihaui neungnyeogeul eotteoke pyeonggahasigetseumnikka." "orgasm (climax)" was translated into "oreugajeum (jeongjeom)" and "oreugajeume" by translator 1 and 2 respectively, and the panels accepted "oreugajeum (seongjeok jeoljeonggam)." The panels added "seongjeok" ("sexual") to describe climax more detailed. "0 Very good 1 Good 2 Fair 3 Poor 4 Very poor to none" in the original questionnaire was translated into " 0 maeu joeum $/ 1$ joeum $/ 2$ botong/3 jochi aneum/4 maeu jochi ankeona eopseum." "Poor" was translated into "jochi anta" and "misuk" by translator 1 and 2 respectively, and the panels accepted "jochi aneum."

Question 8, "How would you describe the usual quality of your erections" in the original questionnaire was translated into "pyeongso gwihaui balgiui jireun eotteoseumnikka." "quality" was translated into "jil" and "gineung by translator 1 and 2 respectively, and the panels accepted "jil." "0 Firm enough/1 Firm enough for masturbation/2 Not firm enough for any sexual activity/4 None at all" in the original questionnaire was translated into "0 chungbunhi dandanham/1 jawihagie chungbunhi dandanham/2 eotteon seonghaengwireul hagiedo chungbunhi dandanhaji aneum/4 balgiga jeonhyeo andoem." "masturbation" was "seonghaengwi" ("sexual activity") by translator 1 and 2 , and the panels accepted "jawi" ("masturbation").

Question 9, "Overall, how much of a problem has your sexual function or lack of sexual function been for you" in the original questionnaire was translated into "jeonbanjeogeuro gwihaui seonggineungina seonggineung bujogi gwihaege eolmana keun munjeyeotseumnikka."

\section{Vitality/Hormonal Symptoms}

Question 10, "How big a problem, if any, has each of the following been for you" in the original questionnaire was translated into "manyak daeume haedanghaneun gakgagui jeungsangi itdamyeon gwihaege eolmana keun munjeyeotseumnikka." "a. Hot flashes or breast tenderness/enlargement" in the original questionnaire was translated into "eolgul hwakkeungeorimina yubangeul nureul." "Hot flashes" was translated into "momui hwakkeungeorim" and "ilgwaseong yeolgam," which mean both "heating sensation of the entire body." The panels accepted "eolgul hwakkeungeorimina" ("sensation of heat, especially in the face"). "b. Feeling depressed" in the original questionnaire was translated into "uulhan neukkim." "c. Lack of energy" in the original questionnaire was translated into "eneoji gamso" and "mugiryeokameul neukkida" by translator 1 and 2 respectively, and the panels accepted "mugiryeokam."

\section{Backward Translation and Retranslation}

As given in (Table 2), all questions in EPIC-CP questionnaire, amended by the panels, were translated in reverse (back-translated), then the panel commented on the distinctions between back-translated text and original text.

In the domain of urinary incontinence, the panels commented on the distinctions between translations of "no urinary control" in the original text and "completely out of control" in the reconciled text. The panels finally agreed to remove "jeonhyeo" in Korean since the phrase "jeonhyeo" made the translation a stronger emphasis on the extent of control.

\section{Cognitive Debriefing and Proofreading}

Ten patients with prostate cancer (aged from 58 to 76 years) completed the revised version of translated questionnaire after the forward and backward translation. Their education levels ranged from elementary school to university (Table 3). 


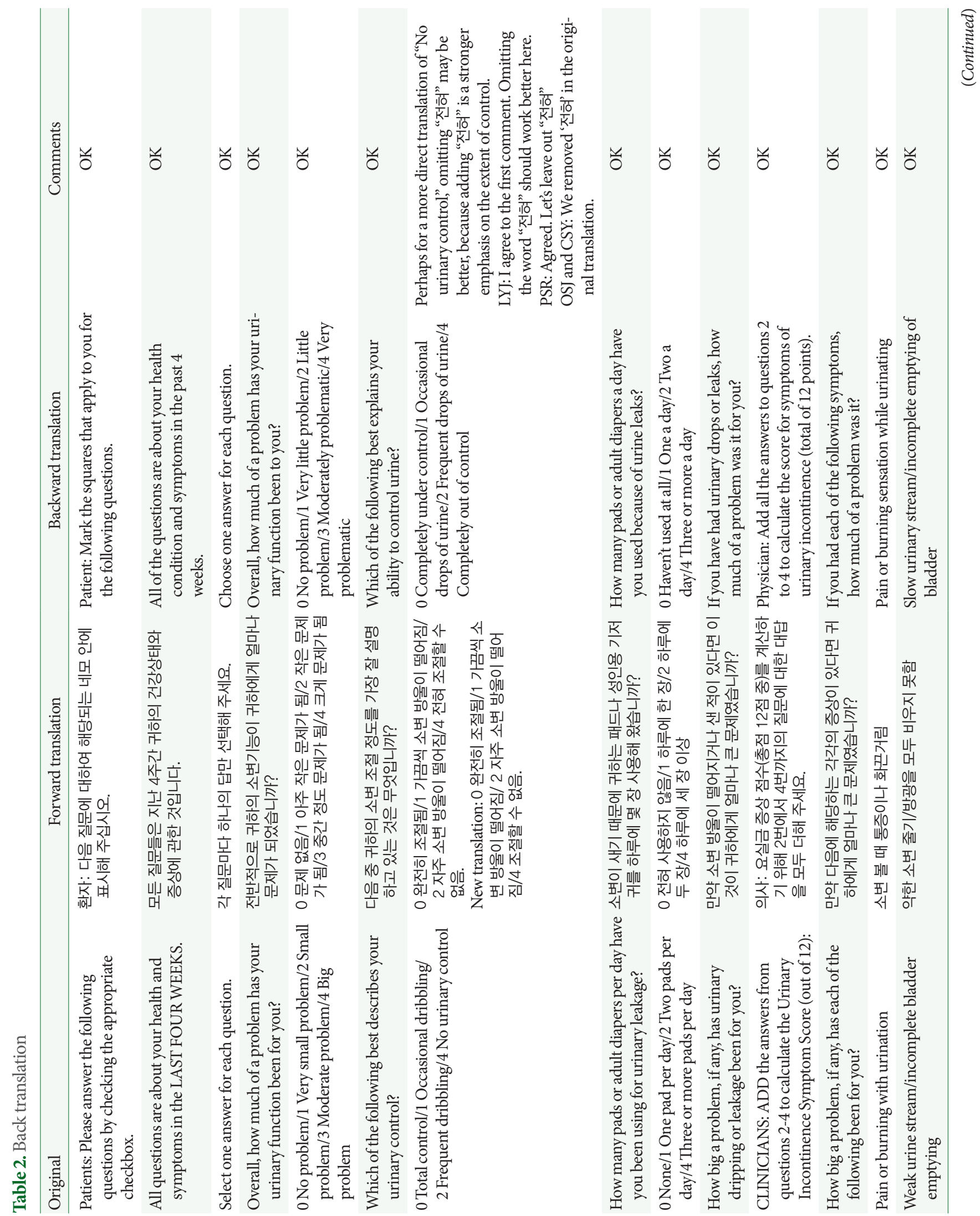









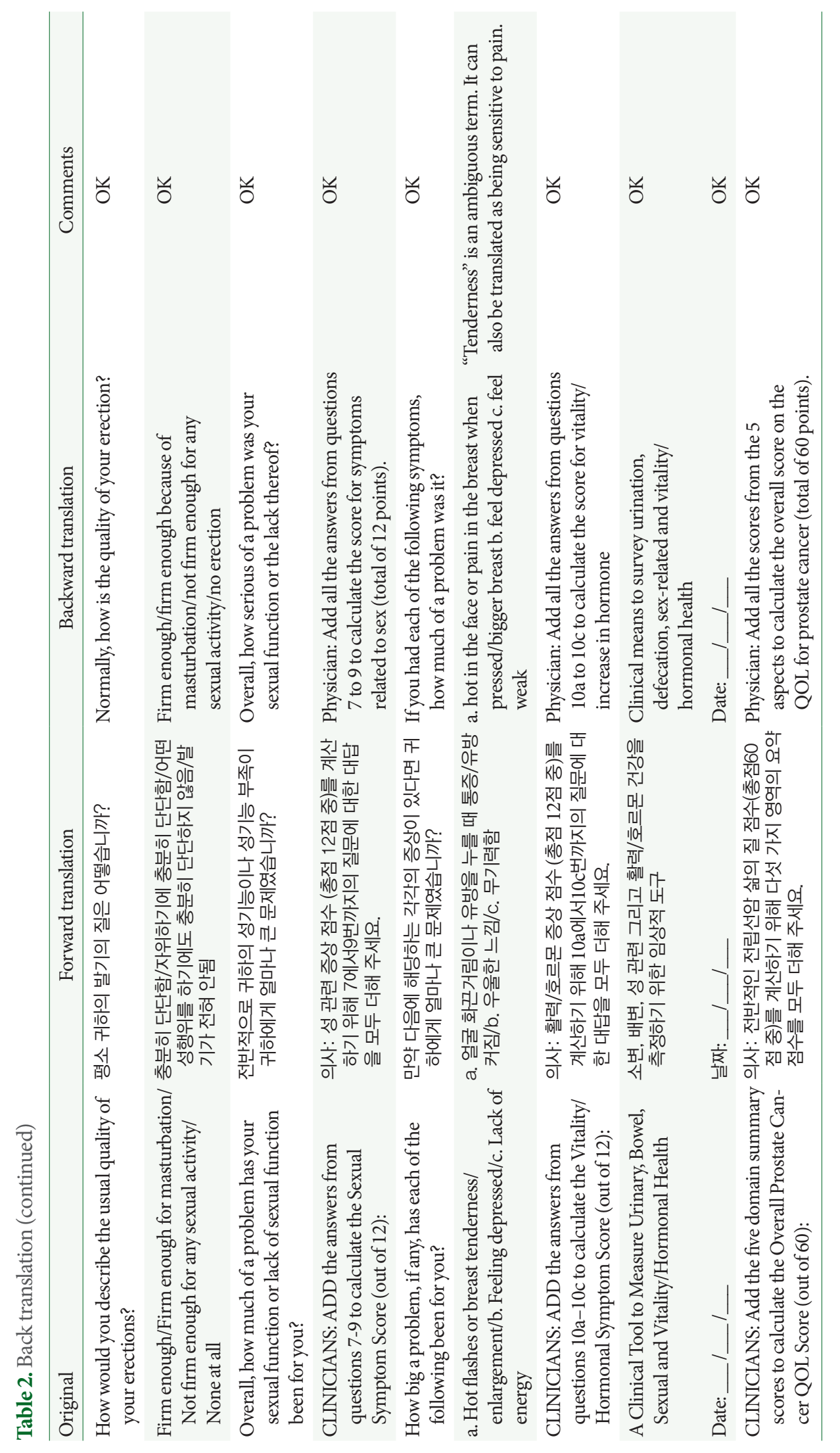


Table 3. Patient data summary sheet

\begin{tabular}{lllccc}
\hline Subject No. & Age & Sex & $\begin{array}{c}\text { Pathology } \\
\text { (stress/urge/mixed) }\end{array}$ & $\begin{array}{c}\text { Profession/ } \\
\text { educational level }\end{array}$ & $\begin{array}{c}\text { Time to complete } \\
\text { questionnaire (min) }\end{array}$ \\
\hline 1 & 65 & Male & PPI & Middle school & 4 \\
2 & 74 & Male & PPI & Elementary school & 8 \\
3 & 67 & Male & PPI & University & 4 \\
4 & 65 & Male & PPI & Unigh school & 4 \\
5 & 72 & Male & PPI & University & 4 \\
6 & 75 & Male & PPI & Elementary school & 4 \\
8 & 58 & Male & PPI & University & 4 \\
10 & 76 & Male & PPI & University & 6 \\
\hline
\end{tabular}

PPI, postprostatectomy incontinence.

They took time for completing the questionnaire from 4 to 8 minutes. Most patients answered that the translated questionnaire was digestible. Two patients did not answer the question 3 because there was no exact number of pads they used. However, the original text contains only 4 choice alternatives, no change was needed. Four patients did not check on each choice alternatives of 5a, 5b, 5c so we added the phrase that "arae gak hangmoge daehayeo ucheugui 0, 1, 2, 3, 4 jung hanaman seontaekayeo jusigi baramnida" in Korean ("Select one of the right choice alternatives $0,1,2,3,4$ for each following question"). The panel ultimately finished translations by comprehensively organizing the expression, and the final version of the translated EPIC-CP questionnaires is shown in Fig. 1.

Some patients were hard to comprehend the expressions in the revised questionnaire. For example, one patient did not understand "sobyeon gineung" and another patient did not understand "seongjeok jeoljeonggam," but it was hard to find alternative expression and only single person did not understand each phrase, so the panels decided not to change it.

\section{DISCUSSION}

The translation of EPIC-CP questionnaires involved inconsistencies among panels and translators. In question 5, "jikjang" was slightly indigestible to general public and some panels suggested the use of hangmun ("anus"). However, hangmun refers to a different part of body and no alternative phrase was available to replace "jikjang" ("rectum"), so the panels selected "jikjang." In question 7, the panel members commented on the dis- tinction between translations of " 2 fair" in the original text and "2 normal" in the reconciled text. One panel suggested that "fair" means normal or average, but it also has a more positive connotation than "normal," whereas "normal" means average or in the middle. The other panels agreed with that suggestion to some degree but it was hard to find an alternative Korean word for "fair," so the panels agreed not to change the reconciled text.

During the translation of multiple overactive bladder questionnaires, few words continued to show a difference between translators and the panel. The word "urgency" was translated as gingeup and gingeupseong by 2 translators, both meaning "emergency" in common. Yojeolbak is a popular translation used in urological publications and the panel agreed on using Yojeolbak. Similarly, symptom-related adjectives such as "urgent" were difficult to translate, and were not retained literally but were replaced by colloquial expressions [10].

The word "moderate" was translated as botong and junggan by 2 translators, and the word "usually" was translated as juro and botong by 2 translators [11]. The translated term botong was used differently by 2 translators. It generally means "normal" or "normally." In the forward translation, the panel reached a consensus regarding the translation of "usually" as juro, but showed inconsistencies in translating "moderate" as botong in Indevus Urgency Severity Scale and junggan in Urgency Perception Scale. The panel reviewed this inconsistency and given the tendency to proceed in the order of "mild," "moderate" and "severe," the members agreed that it was natural to use junggan [11].

In conclusion, our study proposed reliable and suitable lin- 
Expanded Prostate Cancer Index Composite for Clinical Practice (EPIC-CP) 소변, 배변, 성 관련 그리고 활력/호르몬 건강을 측정하기 위한 임상적 도구

환자: 다음 질문에 대하여 해당되는 네모 안에 표시해 주십시오. 모든 질문들은 지난 4주간 귀하의 건강상태와 증상에 관한 것입니다. 각 질문마다 하나의 답만 선택해주세요.

1. 전반적으로 귀하의 소변기능이 귀하에게 얼마나 문제가 되었습니까?

$\square$ 문제 없음 $\square$ 아주 작은 문제가 됨 $\square$ 작은 문제가 됨 $\square$ 중간 정도 문제가 됨 $\square$ 크게 문제가 됨

2. 다음 중 귀하의 소변 조절 정도를 가장 잘 설명하고 있는 것은 무엇입니까?

$0 \square$ 완전히 조절됨 $1 \square$ 가끔씩 소변 방울이 떨어짐 $2 \square$ 자주 소변 방울이 떨어짐 $4 \square$ 조절할 수 없음

3. 소변이 새기 때문에 귀하는 패드나 성인용 기저귀를 하루에 몇 장 사용해 왔습니까?

$0 \square$ 전혀 사용하지 않음 $1 \square$ 하루에 한 장 $2 \square$ 하루에 두 장 $4 \square$ 하루에 세 장 이상

4. 만약 소변 방울이 떨어지거나 샌 적이 있다면 이것이 퀴하에게 얼마나 큰 문제였습니까?

$\square$ 문제 없음 $\square$ 아주 작은 문제가 됨 $\square$ 작은 문제가 됨 $\square$ 중간 정도 문제가 됨 $\square$ 크게 문제가 됨 의사: 요실금 증상 점수 (총점 12점 중)를 계산하기 위해 2 번에서 4 번까지의 질문에 대한 대답을 모두 더해 주세요.

5. 만약 다음에 해당하는 각각의 증상이 있다면 귀하에게 얼마나 큰 문제였습니까? (아래 각 항목에 대하여 우측의 $0,1,2,3,4$ 중 하나만 선택하여 주시기 바랍니다)

a. 소변 볼 때 통증이나 화끈거림

b. 약한 소변 줄기 / 방광을 모두 비우지 못함

c. 소변을 자주 봐야 함

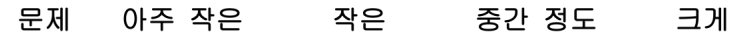

없음 문제가 됨 문제가 됨 문제가 됨 문제가 됨

\begin{tabular}{lllll}
\hline $0 \square$ & $1 \square$ & $2 \square$ & $3 \square$ & $4 \square$ \\
$0 \square$ & $1 \square$ & $2 \square$ & $3 \square$ & $4 \square$ \\
$0 \square$ & $1 \square$ & $2 \square$ & $3 \square$ & $4 \square$ \\
& 의사: 요 자극/페색 증상 점수 (총점 12점 중)를 계산하기 위해 \\
& $5 \mathrm{a}$ 에서 $5 \mathrm{c}$ 까지의 질문에 대한 대답을 모두 더해 주세요.
\end{tabular}

6. 만약 다음에 해당하는 각각의 증상이 있다면 귀하에게 얼마나 큰 문제였습니까? (아래 각 항목에 대하여 우측의 $0,1,2,3,4$ 중 하나만 선택하여 주시기 바랍니다)

a. 직장 통증 혹은 급박한 배변감

b. 배변 횟수의 증가

c. 귀하의 배변 습관에 대한 전반적인 문제


없음 문제가 됨 문제가 됨 문제가 됨 문제가 됨

\begin{tabular}{lllll}
\hline $0 \square$ & $1 \square$ & $2 \square$ & $3 \square$ & $4 \square$ \\
$0 \square$ & $1 \square$ & $2 \square$ & $3 \square$ & $4 \square$ \\
$0 \square$ & $1 \square$ & $2 \square$ & $3 \square$ & $4 \square$ \\
& 의사: 배변 증상 점수 (총점 12점 중)를 계산하기 위해 \\
& $6 a$ 에서 6 c)ㄲ지의 질문에 대한 대답을 모두 더해 주세요.
\end{tabular}

7. 오르가즘 (성적 절정감)에 이를 수 있는 귀하의 능력을 어떻게 평가하시겠습니까?

$0 \square$ 매우 좋음 $1 \square$ 좋음 $2 \square$ 보통 $3 \square$ 좋지 않음 $4 \square$ 매우 좋지 않거나 없음

8. 평소 귀하의 발기의 질은 어떻습니까?

$0 \square$ 충분히 단단함 $1 \square$ 자위하기에 충분히 단단함
$2 \square$ 어떤 성행위를 하기에도

충분히 단단하지 않음

9. 전반적으로 귀하의 성기능이나 성기능 부족이 귀하에게 얼마나 큰 문제였습니까?

$\square$ 문제 없음 $\square$ 아주 작은 문제가 됨 $\square$ 작은 문제가 됨 $\square$ 중간 정도 문제가 됨 $\square$ 크게 문제가 됨

의사: 성 관련 증상 점수 (총점 12점 중)를 계산하기 위해 7 에서 9 번까지의 질문에 대한 대답을 모두 더해 주세요

10. 만약 다음에 해당하는 각각의 증상이 있다면 귀하에게 얼마나 큰 문제였습니까? (아래 각 항목에 대하여 우측의 $0,1,2,3,4$ 중 하나만 선택하여 주시기 바랍니다)
a. 얼굴 화끈거림이나 유방을 누를 때 통증 /유방커짐
b. 우울한 느낌
c. 무기력함

\section{문제 아주 작은 작은 중간 정도 크게 없음 문제가 됨 운제가 됨 문제가 됨 운제가 됨}

\begin{tabular}{|c|c|c|c|c|}
\hline $0 \square$ & $1 \square$ & $2 \square$ & $3 \square$ & $4 \square$ \\
\hline $0 \square$ & $1 \square$ & $2 \square$ & $3 \square$ & $4 \square$ \\
\hline $0 \square$ & $1 \square$ & $2 \square$ & $3 \square$ & $4 \square$ \\
\hline \multicolumn{5}{|c|}{$\begin{array}{l}\text { 의사: 활력/호르몬 증상 점수 (총점 12점 중)를 계산하기 위해 } \\
\text { 10a에서 10c번까지의 질문에 대한 대답을 모두 더해 주세요. }\end{array}$} \\
\hline
\end{tabular}

Fig. 1. Korean version of the Translation and Linguistic validation of Korean version of the Expanded Prostate Cancer Index Composite for Clinical Practice for patients with prostate cancer. 
guistic validation of the EPIC-CP questionnaires in Korean. HRQoL was also emphasized in patients with prostate cancer. The Korean version of EPIC-CP translation can be used to evaluate the severity of symptoms in Korean patients with prostate cancer.

\section{ACKNOWLEDGMENTS}

This article was supported by the members of the Questionnaire Investigation Committee of the Korean Continence Society. Seung-Ee Kim performed previous linguistic validation study and supported this article.

\section{AUTHOR CONTRIBUTION STATEMENT}

- Conceptualization: $Y C H, S Y C, J H K, S J J, S J O$

- Data curation: YCH, SYC, SJJ, SJO

- Formal analysis: $Y C H, S Y C$

- Funding acquisition: $Y C H, S Y C$

- Methodology: YCH, SYC, JH Ku, SJJ, SJO

- Project administration: YCH, SYC, JH Ku, SJJ, SJO

- Visualization: $Y C H, S Y C$

- Writing-original draft: $Y C H, S Y C$

- Writing-review \& editing: $Y C H, S Y C$

\section{ORCID}

$\begin{array}{ll}\text { Sung Yong Cho } & 0000-0001-9271-6951 \\ \text { Seong Jin Jeong } & 0000-0002-3580-1452 \\ \text { Seung-June Oh } & 0000-0002-0322-3539\end{array}$

\section{REFERENCES}

1. Litwin MS, Hays RD, Fink A, Ganz PA, Leake B, Leach GE, et al. Quality-of-life outcomes in men treated for localized prostate cancer. JAMA 1995;273:129-35.

2. Wei JT, Dunn RL, Litwin MS, Sandler HM, Sanda MG. Development and validation of the expanded prostate cancer index composite (EPIC) for comprehensive assessment of health-related quality of life in men with prostate cancer. Urology 2000;56:899905.

3. Litwin MS, Hays RD, Fink A, Ganz PA, Leake B, Brook RHJMc. The UCLA Prostate Cancer Index: development, reliability, and validity of a health-related quality of life measure. Med Care 1998; 36:1002-12.

4. Szymanski KM, Wei JT, Dunn RL, Sanda MGJU. Development and validation of an abbreviated version of the expanded prostate cancer index composite instrument for measuring health-related quality of life among prostate cancer survivors. Urology 2010;76:124550.

5. Chang P, Szymanski KM, Dunn RL, Chipman JJ, Litwin MS, Nguyen PL, et al. Expanded prostate cancer index composite for clinical practice: development and validation of a practical health related quality of life instrument for use in the routine clinical care of patients with prostate cancer. J Urol 2011;186:865-72.

6. Kim SE, Lee HS, Lee HN, Lee SY, Choo MS, Park MG, et al. Korean translation and linguistic validation of urgency and overactive bladder questionnaires. Int Neurourol J 2020;24:66-76.

7. Kang SH, Oh SJ, Jeong SJ, Cho SY. Linguistic Validation of the intermittent self-catheterization questionnaire for patients with neurogenic bladder who perform intermittent catheterization for voiding dysfunction. Int Neurourol J 2019;23:75-85.

8. Lee HN, Chae JY, Lee HS, Choo MS, Park MG, Lee SY, et al. Translation and linguistic validation of the Korean version of the treatment satisfaction visual analogue scale and the overactive bladder satisfaction with treatment questionnaire. Int Neurourol J 2017; 21:309-19.

9. Cho SY, Lee HE, Jeong SJ, Oh SJ. Translation and linguistic validation of the Korean version of the "benefit, satisfaction, and willingness to continue" questionnaire for patients with overactive bladder. Int Neurourol J 2016;20:255-9.

10. Acquadro C, Kopp Z, Coyne KS, Corcos J, Tubaro A, Choo MS, et al. Translating overactive bladder questionnaires in 14 languages. Urology 2006;67:536-40.

11. Yoon YE, Cho SY. Translation and linguistic validation of the Korean version of the Wisconsin Stone Quality of Life Questionnaire. Int Neurourol J 2020;24:77-83. 